\title{
Feasibility Study on E-business Website Project of Voluntourism
}

\author{
Lili Jing \\ Changchun University of Finance and Economics \\ Changchun, China
}

\author{
Yuzhe Wang \\ Changchun University of Finance and Economics \\ Changchun, China
}

\author{
Jiaqi Zhang \\ Changchun University of Finance and Economics \\ Changchun, China
}

\begin{abstract}
Tourism has been defined as national economic strategic leading industry. National entertainment industry is also becoming a new economic growth-point. The syncretism between tourism and other industries is enhanced and new formats emerged continuously. The market requirement in tourism appeared to be more diversified. In this background, in order to cultivate tourism majors' practical ability and innovative ability, a voluntourism website is established based on E-business and unique characteristics of tourism. This paper elaborated business mode, operation content, and source of income of the project. It also conducted SWOT analysis on its feasibility as well as put forward project development strategy in general.
\end{abstract}

Keywords-voluntourism; E-business website project; SWOT analysis

\section{INTRODUCTION}

With great efforts from the operators and higher popularities among customers, Chinese online tourism market is growing. The market scale reached 28 billion yuan in 2016. The number may rise to 35 billion yuan by 2020 , which indicates a prosperous future.

www.gylv.com is a B2C E-business traveling agent website, combing both $\mathrm{C} 2 \mathrm{C}$ and $\mathrm{O} 2 \mathrm{O}$ modes. Through voluntourism, it aims to expand the approach and the market of tourism, motivate passions for public services nationwide, find proper balance between public welfare and corporate profit, develop new tourism resources, and unveil the charms

Research Projects:

1. Emphasized Project in Educational Science Plan of Jilin Province in 2016: A Study on Teaching Reformation of Private Universities Based on CBE Mode. (Contract No. ZD16070)

2. Project of Jilin Association for Higher Education in 2016: A Study on the Application of Company Assimilation Mode in Marketing Major's Training Session. (Contract No. JGJX2016D164)

3. Teaching Reformation and Establishment Project, Changchun University of Finance and Economics.

4. 13th 5-year-plan Social Science Research Project, the Education Department of Jilin Province: Research on Transformation and Elevation of Electronic Information Industry in Jilin Province from the Perspective of Self-Innovation. (Contract No. [2016]559) of tourism.

In form, it is the combination of E-business, volunteer work and tourism. When introducing commonweal traveling resources and conducting relevant activities, the voluntourism website provides customers and traveling resource enterprises with a whole new way of leisure by means of convenient and charitable activities and podcasting. Facing customers and traveling resource enterprises from all over the country, this website offers services as charitable commonweal services of tourism, charitable community services of tourism, charitable donation services of tourism, and charitable recommendation of tourism etc. www.gylv.com has taken an important position in E-business field under both opportunities and challenges since it caught three major characteristics, namely, taking commonweal as operational content, specializing service targets, and diversifying profit mode.

\section{BUSINESS MODE}

www.gylv.com and other platform based tourism enterprises both realize their profits via tourism popularization and connection. However, www.gylv.com has unique commonweal features, which allows corporate activities and commonweal behaviors connect seamlessly. The enterprise grows as its commonweal service increases.

\section{A. Service Targets}

Initially, the service is offered to individuals and enterprises conducting commonweal. It gradually developed and covered the general public and all tourism enterprises. Eventually, the service is provided for all industries and the whole population.

\section{B. Requirements}

In a pan-tourism era, many people have desires of traveling. In this situation, people welcome traveling activities which are cheap and well organized as well as involving charities. 


\section{Supplies}

As long as proper places with traveling value can be provided, there is a great demand towards individuals, enterprises, communities and organizations. For example, visits to industrial enterprise can be developed into industrial tourism. Meanwhile, it would be better for the individuals and enterprises to provide commonweal discount so that it can be used as commonweal fund to donate to people in poverty regions.

\section{OPERATIONAL CONTENT AND SOURCE OF INCOME}

The website mainly offers platform services between tourism resource enterprise and tourist.

\section{A. Core Business}

The core business is voluntourism, namely, part of the income from voluntourism business is transferred into commonweal fund and given out to people who suffer from poverty through commonweal channel.

1) Commonweal hotel: This website provides quality hotel resources with discount commonweal fund. The voluntourists enjoy the discount from the hotel and the discount part will return to the platform website as commonweal fund. Besides commonweal hotel, people can also find commonweal homestay on the website.

2) Commonweal attractions: This website provides quality attraction resources with discount commonweal fund. The voluntourists enjoy the discount from the hotel and the discount part will return to the platform website as commonweal fund. The website offers services, education, volunteers and layout plans in commonweal attractions.

3) Commonweal traveling agency: This website provides commonweal agency services and group traveling services to tourism resource enterprise and tourist. The website takes platform commonweal fund and offers commonweal traveling group, tour guide, and charity team etc..

4) Voluntourism: Through voluntourism activities, it stimulates passions of the participants, expanding customers of voluntourism, developing educational traveling between countries and cities. The website can carry out commonweal traveling focusing on introducing techniques and skills to people in remote places, caring left-behind children in country side, educating students in poverty areas, developing new attractions and charitable traveling in famous traveling enterprises etc.

5) Commonweal business trip: This website customizes business trip for commonweal enterprise clients. For example, commonweal traveling for aiding and helping, free tour for employees of the year in commonweal enterprises etc..

6) Commonweal transportation: This website provides charity-based motorcade and Leifeng motorcade, establishing volunteer searching organization, which helps voluntourists voluntarily in their transportation. By using commonweal transportation network, the cost for logistics can be ignored. This leads to a real volunteer relay and forms a system with national airlines, railways, shipments and road transportation. Commonweal discount tickets are released constantly on the website.

7) Commonweal mall: Commonweal mall takes commonweal profit from the buyers and sellers and uses it as commonweal fund.

8) Commonweal credit: All activities organized by individuals or enterprises are credited. The credit can be used as an exchange for commonweal product, commonweal activity, commonweal traveling, commonweal ranking recommendation, commonweal publication and commonweal popularization etc.

9) Commonweal fund: All commonweal profit will be transferred into commonweal fund, which will be allocated by the website in order to maximize its effect on those who call for helps.

10) Commonweal member: All enterprises and individuals should join in as a member.

\section{B. Supporting Business}

With the view of developing major business, the website also needs to be good at detailed business service and support, turning the enterprises into thoughtful steward, trusting friend and partners.

1) Traveling information services: www.gylv.com is a platform for attractions, restaurants, hotels, traveling rental companies, traveling agencies etc. to exhibit their information. Therefore, they can attract more customers and earn more profits through this website.

Additionally, commonweal popularity can be measured via voting and credit rating.

The website will also release programs like "sales", "discounting" etc. regularly to lure more customers trading with the sellers.

2) Recommendation service of commonweal product: Besides common buyers and sellers, there are also commonweal buyers and commonweal sellers. Part of the commonweal products are non-profit products circulated to poverty regions. As for the beneficiaries in these regions, they can manufacture and sell local product to increase income and get rid of poverty.

3) Recommendation service of commonweal transportation: www.gylv.com makes recommendation service through app and internet, providing commonweal platform for car owner who can give a lift, and introducing most convenient commonweal transportation service to voluntourists. At the same time, it also affords intelligent recommending system and sharing road map service as it cooperates with Baidu and explored a complete map service and coordinates application information.

4) Podcasting: Podcasting on www.gylv.com will make you a commonweal host and commonweal online celebrity. People can participate in spokesperson activity and earn 
satisfactory income. Part of the income can be used as commonweal fund.

\section{Source of Income}

The customers' sincerity and satisfaction are increased as a result of offering a large number of free services by backcharging mode. The income can be gained in the following ways:

- Commission income from trading volume of commonweal hotels;

- Income from advertising campaign of commonweal traveling sellers;

- Membership charges of commonweal traveling agencies;

- Membership charges of registered commonweal traveling enterprises;

- Incomes from commonweal online mall;

- Income from commonweal podcasting;

- Commission income from trade volume of commonweal transportation;

\section{SWOT ANALYSIS OF VOLUNTOURISM E-BUSINESS} WEBSITE

\section{A. Strength}

It should clear commonweal features. The project dedicated to commonweal and focuses on commonweal features.

1) Platform-based enterprise: Modern enterprises have experienced three phases. Phase 1, the appearance of plants. Phase 2, the appearance of companies. Phase 3, the appearance of platform-based enterprises which are super vital and competitive.

2) Podcasting and podcasting-implanted website: A large number of audience are post-90s and post-00s. They are fond of blog and podcasting. As a result, both of them are incorporated in voluntourism website to raise more attentions from the younger generation.

3) Exchange mode for voluntourism education: This kind of education will get more families involved in.

4) Enterprise propaganda of voluntourism: By doing more commonweal enterprise propaganda, more enterprise users take part in.

5) Quantified commonweal accumulation based on credits: Quantified commonweal accumulation strengthens the effectiveness of voluntourism and arise passion of participating commonweal from individuals and enterprises.

6) Self-selection voluntourism: This project has many forms of voluntourism, which cast away old style of commonweal, easing voluntourism and increasing participation.

\section{B. Weakness}

1) Financial difficulties: Facing with a new technique, most of people may hold their view and ride the fence. Because this project has just started and is not famous enough, so it can only attract fewer investors which will lead to hard management due to lack of capitals in the initial stage.

2) Lack of technicians: This project chose selfdevelopment as website developing strategy. However, due to tourism graduates having insufficient internet techniques, this project still requires a stable technician team to solve critical technique problems. Because of limited finance, it is not possible to hire technicians for long terms with high salaries.

3) No referential business mode: This website's operation involves in commonweal field, a relatively new field for websites. Thus, there is no established business mode for reference. There are of course shortcomings in current operations that people are unable to evaluate the field from a complete perspective so that put forward narrow understandings. This is both weakness and opportunities.

4) Limitations in initial stage: This project's service product is the integration of all traveling resources enterprise. Currently, the tourism in China develops quickly. The high quality traveling resources are small in number. Traveling enterprises may not surrender part of the profits to consumers in the form of commonweal fund. All these will hinder the development of the website in short term. The situation will be improved in the future.

5) Difficulties in marketing: At the initial stage, it is very important to solve the problem of getting more travelers know the website and increasing number of people visiting the website. It is necessary to convince some of the attractions, hotels, restaurants and equipment stores to establish cooperation, using website to publish traveling information and conduct online trade. Resulting from being a newly founded website and targeting busy white-collars, new marketing approach is needed to advertise.

\section{Opportunities}

1) The number of netizens is growing consistently: The continuous spreading financial crisis worldwide has not yet influenced China too much. CNNIC report illustrated that the number of netizens grows quickly. China has the largest internet scale in the world. By December 2016, the number has reached 0.467 billion, showing an excellent progress and stepping into a new round of fast-development phase.

2) Abundant traveling resources: Iresearch released a report on Chinese Landscape traveling research, 2016. The report displayed that, by 2015, there are over 7000 A-class landscapes. Among them, there are more than 1500 5A and 4A landscapes. With the development of internet, the online landscape ticket market has increased dramatically by 
$57.2 \%$, which is 9.04 billion yuan. It is estimated that this market may breakthrough 15 billion yuan by 2017 .

3) Rigid demand in voluntourism: According to the statistics from national tourism administration and the practice in tourism market, pan-tourism has arrived. From superior resource industry, tourism has become extensive resource industry. All kinds of tourism emerged in endless streams. Tourist also brought diversified rigid requirements forward. Therefore, it is a must to integrate commonweal website of voluntourism.

4) Huge market potentials: In China, the B2B for traveling E-business is in a developing phase. Many trade in traveling agencies, airline, hotels and attractions brought enormous potentials. $\mathrm{C} 2 \mathrm{C}$ is rising and $\mathrm{O} 2 \mathrm{O}$ is also strengthening. Hence, there still is a huge gap between China and developed countries. It is both opportunity and challenge for this project. Seizing this opportunity, commonweal can take a position in traveling E-business industry.

5) Innovative services: Due to the differences between voluntourism project and traditional donation, this website provides abundant and meaningful voluntourism mode and voluntourism education mode. This innovation will definitely arouse more attentions from the general public.

6) Podcasting: The internet is getting more common and more convenient. The podcasting is very popular, especially for those who work a lot. They want to relax urgently and stay the pressures of family and work away.

7) The pursuit for civil traveling: The material quality increases, and the moral and civil quality increase as well. The volunteer work has expanded to a large extent. People's commonweal awareness continues to grow which offered a proper environment for the development and expansion of voluntourism website.

\section{Threats}

1) Heavy work load leading to limited time on internet: In modern society, the competition grows so people have to spend more time on work or even work extra hours. Consequently, people don't have much time to search information online. Also, the elder generation is unable to master adequate computer skills. For these reasons, promoting the website is hard.

2) Speculative purpose from the investors: After the economic foam at the beginning of the 21st century, investors have their sense back concerning internet business. It is no longer appropriate to apply high risk, high investment and high reward theory in current internet market. Investors would have already thought about how to retrieve their money when they are still deciding whether to invest a project or not. Therefore, at the starting phase, it is critical to finance effectively, maintain unimpeded cash flow, form a virtuous circle and acquire the faith from the investors. Otherwise, a sudden pulling back may bring catastrophe $t$ the enterprise.
3) Threats from search engines and specialized websites: Internet in China develops quickly. Most of the tourists fall into the habit of using search engines like Baidu to find the information they need. The specialized business trip websites are becoming first choice for business people. The biggest threats to this project are search engines like Baidu and websites such as Quna'er with powerful information resources. Moreover, the operation mode is likely to be imitated by other websites at the beginning. The threat can also arise from the established website's acquisition or suppression.

\section{SWOT INTEGRATED STRATEGY}

According to the above analysis, this project integrated different types of strategy so that the target can be reached successfully.

\section{A. Presupposition of Future Market}

This project may not profitable due to insufficient finance and unpopularity. The situation can be reversed because of its customized service, specialized service targets and diversified profit mode. When this project gradually builds a virtuous circle, it certainly can become an important part in traveling E-business field.

\section{B. SO Strategies}

- Strategy 1: customizing service in order to fulfil the customer requirements

- Strategy 2: strengthening the attractions of the website to customers

- Strategy3: introducing the website through diversified marketing integration strategy

- Strategy 4: enhancing the management of the customer group

\section{WO Strategies}

- Strategy 1: reinforcing the cooperation with other famous enterprises and acquire finance from multiple channels.

- Strategy 2: outsourcing technique and take advantage of resources from outside.

- Strategy3: exploring new markets and predominate the market share beforehand.

\section{ST Strategies}

- Strategy 1: introducing the website to specialized service group by utilizing propaganda approaches.

- Strategy 2: adopting differentiation strategy to reduce imitations

- Strategy 3: learning from popular and famous websites and framing unique customized service 
- Strategy 4: intensifying the management on human resources, finance and techniques to minimize the cost

\section{E. WT Strategy}

- Strategy 1: strengthening department management and reduce unnecessary expenditures.

- Strategy 2: establishing a proper recruitment and training system to discover more excellent employees.

- Strategy 3: decreasing risks by constant supervision and control.

\section{CONCLUSION}

Based on the analysis above, to promote voluntourism website, it is vital to apply different marketing strategies to different clients. Therefore, www.gylv.com should adopt an overall marketing strategy, including two groups, four basics, multiple methods so that commonweal brand can be established. Two groups refer to the business group and the potential tourist group. Four basics are the emphasis in the marketing process on "bringing more benefits for the website and offline entities", "reducing traveling burdens", "sharing route" and "rewarding bonus". Multiple methods indicate to establish a firm voluntourism brand by utilizing current resources, highlighting distinguishing features and innovating approaches. All in all, voluntourism's overall marketing strategy is to promote through collaboration and competition. It not only involves the attention paid to the marketing of relevant enterprises, but also the study conducted on marketing of rivals, so that an orderly market for competition can be established.

\section{REFERENCES}

[1] Yu, Liqiong \& Yin, Qihua. A Calm Thinking of Country Tourism in China[J]. Journal of Guangdong University of Petrochemical Technology,2017(04).

[2] Wang, Tianliang. Approaches of Elevating Traveling Experience by Doing Intelligent Tourism[J]. Science and Technology, 2015(31)

[3] Li, Jialan. Research on Elevating Traveling Experience under the Background of Intelligent Tourism [J].China Collective Economy, 2016(22).

[4] Zhang, Xinran \& Sun, Jie. An Analysis on the Influence of the Development of Intelligent Tourism to Tourist's Traveling Experience [J]. Tourism Overview,2016(08).

[5] Zhang, Yuli \& Xu, Tong. Research on the Core of Tourism Theory from the Perspective of Traveling Experience [J]. Tourism Overview,2014(10). 